\title{
WORKING
}

paper

\section{Bank Equity Value and Loan Supply}

\section{Mattia Girotti ${ }^{1}$ and Guillaume Horny ${ }^{1}$}

\author{
May 2020, WP \#767
}

\begin{abstract}
We study how bank equity values affect loan supply. We exploit granular balance sheet information on euro area banks matched with financial market data. We address endogeneity concerns by instrumenting bank stock prices with a shifter derived from each bank stock price's sensitivity to non-financial corporations' equity values. Our results indicate that, other things equal, rises in bank stock prices cause increases in corporate and household lending, and in bank capitalization. We interpret these results as due to bank managers reading the rises in their bank's stock price as reductions in their bank's cost of equity.
\end{abstract}

Keywords: Banks, Stock Prices, Loan Supply, Equity Funding.

JEL classification: G21, G31, G32.

\footnotetext{
${ }^{1}$ Financial research dept. mattia.girotti@,banque-france.fr; guillaume.horny@,banque-france.fr

We thank Charles Calomiris, Andrea Tiseno, and seminar and conference participants at the University of Zurich and the Central Bank of Ireland for helpful comments. We also thank Benoît Mojon for kindly sharing data on euro area bank bond yields with us.

Working Papers reflect the opinions of the authors and do not necessarily express the views of the Banque de France. This document is available on publications.banque-france.fr/en
} 


\section{NON-TECHNICAL SUMMARY}

The ability for banks to lend to households and firms depends on the conditions at which they borrow. Banks' funding mix is typically composed of deposits, bonds, and equity. The extent to which shocks on deposit and bond funding transmit to loan supply is one of the most studied topics in the banking literature. Conversely, far less attention has been devoted to how shocks on equity funding reverberate on loan supply. One reason lies in the fact that the cost of equity -- i.e. the remuneration required by stock investors to hold the equity of a firm -- is not directly observable.

In this paper, we proxy for each bank's cost of equity by building on stock valuation techniques. These techniques imply that while controlling for bank fundamentals such as the dividends per share, the stock price of a bank relates negatively to the cost of equity required by the bank's investors. This provides us with a way to assess the effect of the bank cost of equity on loan supply. Specifically, in our analysis, we examine the impact of bank stock prices on loan supply, while controlling for bank fundamentals through variables such as each bank's dividends per share, earnings per share, CDS price, balance sheet ratios, together with country-time and bank fixed effects.

We implement this analysis on a sample of 68 banks from 12 euro area countries. The period on which we focus is from 2010Q2 to 2019Q2. The data we exploit includes granular information on bank balance sheets and comes from the ECB. These data are merged with bank-specific financial market information from Datastream and Bloomberg.

We first conduct a graphical analysis. We relate the sampled banks' (log-) stock price to the banks' corporate loan growth in the following year. ${ }^{2}$ The resulting scatter plot appears below. It shows that the (log-) stock price associates positively with loan growth, indicating that a lower cost of equity is related to greater loan supply.

When we bring the equation sketched above to the data, we find confirmation of a positive association of bank (log-) stock prices with loan supply to households and firms. However, it is possible that these results are due to some unobservable elements, which simultaneously affect both bank stock prices and bank loan supply. We cope with this endogeneity issue by using an instrumental variable.

We construct a bank-quarter specific instrument based on the idea that a bank's net worth, and thus its stock price, depend on the bank's portfolio of investments and on how this reacts to macroeconomic conditions. We first measure the sensitivity of each bank's stock price daily returns to the daily returns of an index representing euro area non-financial corporations, over one-year long rolling windows. We predict the trajectory that each bank's stock price should have taken given the realization of that index and the bank's historical relationship with it. We then use the quarterly returns in these fictional trajectories as an instrument for banks' stock prices.

Armed with this instrument, we assess the effect of bank stock prices on loan supply. We find confirmation of the OLS estimates. The effects are quantitatively important, especially considering that they are net of changes in bank fundamentals, and of macroeconomic conditions: every $10 \%$ increase in a bank's stock price corresponds to a rise in corporate and household lending of $0.32 \%$ of the bank's total assets. For a median bank, this means more loans to corporations and households for an amount equal to $€ 260$ million.

Our reading of these results is that bank managers interpret an increase in their bank's stock market value as a reduction in the cost of equity requested to the bank by market investors. They thus react by lending more. However, if this mechanism underpins our results, we

\footnotetext{
${ }^{2}$ Preliminarily, we rescale the two variables to lie within 0 and 1 , for each bank.
} 
should also find that in parallel to greater lending, bank managers exploit the relaxed equity funding conditions by increasing their stock of equity. We test this by using our identification strategy. We find confirmation of the mechanism: banks do react to an increase in their stock price by increasing their stock of equity.

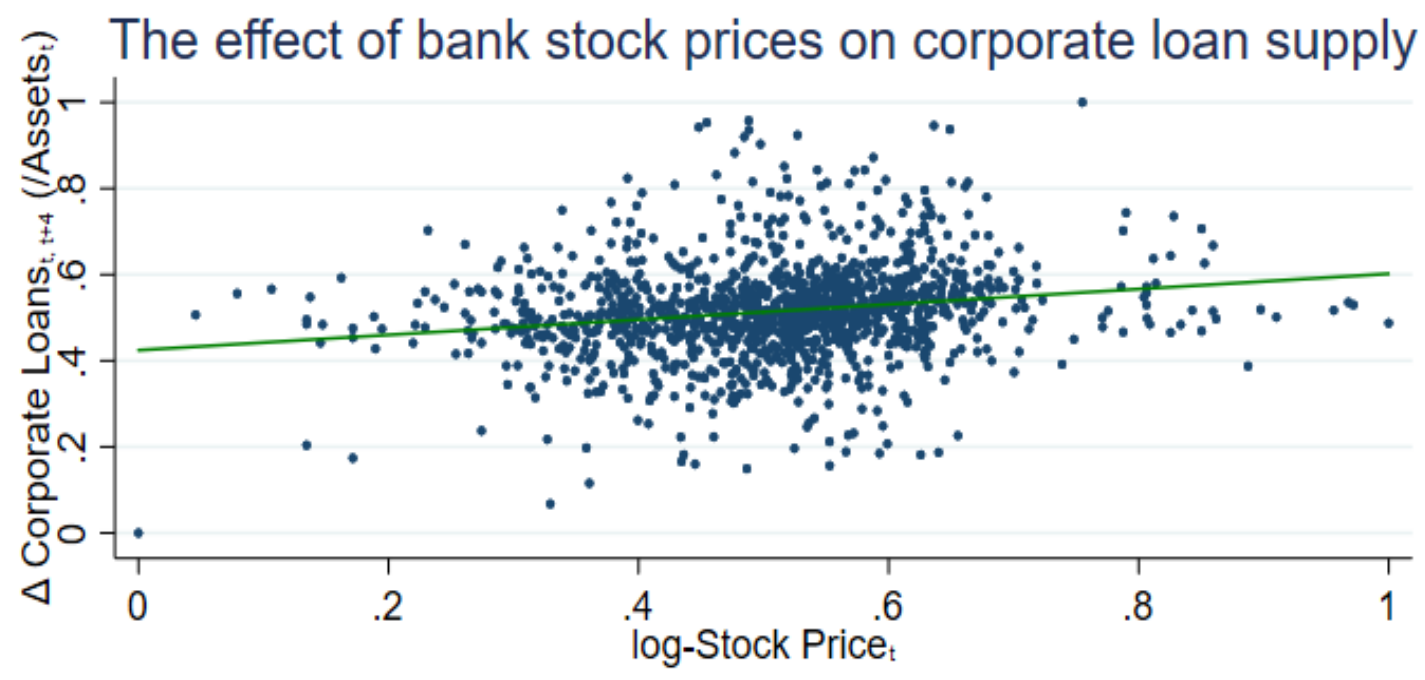

Source: Girotti and Horny (2020)

\section{Valeur des fonds propres bancaires et offre de prêts}

\section{RÉSUMÉ}

Nous étudions comment le cours des actions des banques affecte l'offre de crédit. Nous utilisons des informations granulaires sur les bilans des banques de la zone euro associées à des données des marchés financiers. Nous traitons des problèmes d'endogénéité en instrumentant les cours des actions bancaires avec une mesure de la sensibilité de la valeur de marché de chaque banque à la valeur de marché des sociétés non financières. Nos résultats indiquent que, toutes choses égales par ailleurs, une hausse des cours des actions bancaires entraîne une augmentation des prêts aux entreprises et aux ménages et de la capitalisation bancaire. Nous interprétons ces résultats comme étant dus au fait que les directeurs de banque lisent les hausses du cours des actions de leur banque comme des réductions du coût des fonds propres de leur banque.

Mots-clés : banques, cours des actions, offre de prêts, financement par actions. 


\section{Introduction}

Funding conditions are of crucial importance for credit institutions, as their ability to lend depends on the price and the quantity of the funds that they collect. The extent to which shocks on deposit and bond funding transmit to loan supply is one of the most studied topics in the banking literature. ${ }^{1}$ Conversely, far less attention has been devoted to how shocks on equity funding reverberate on loan supply. One reason lies in the fact that the cost of equity - i.e. the remuneration required by stock investors to hold the equity of a firm - is not directly observable. Another reason is that, unlike other liabilities, equity does not need to be rolled-over. It is thus not clear to what extent shocks on its cost would impact a bank's lending policy. Assessing how equity funding conditions affect bank loan supply is however of great interest: equity accounts for a significant fraction of bank liabilities, and, especially in the euro area, bank loans are the main source of financing for households and small firms.

This paper builds on the fact that the market value of banks is closely connected with their cost of equity: indeed, stock valuation techniques indicate that the intrinsic value of a firm's stock depends on the firm's expected cash dividends per share discounted at the firm's cost of equity. Based on this simple argument, we proxy for each bank's cost of equity by using the bank's equity value, and examine whether bank equity values impact bank loan supply to firms and households. We employ unique granular balance sheet information on 68 banks from 12 euro area countries, matched with financial market information on bank stock prices, dividends-per-share, earnings-per-share, and Credit Default Swap (CDS) prices. The sample has quarterly frequency and spans from 2010Q2 to 2019Q2. Our empirical investigation contrasts asset allocation across banks within the same country and the same time period, and thus exploits banks' heterogeneity along both the temporal and the cross-sectional dimensions.

More precisely, we measure a bank's (future) loan supply by the loan growth realized from quarter $t$ to $t+4$, scaled by total assets at $t$. We distinguish between loan supply to households, to non-financial corporations, and to other banks. We then regress the created mesures of

\footnotetext{
${ }^{1}$ See, e.g., the literature on the bank lending channel of monetary policy transmission following Bernanke and Blinder (1988) and Bernanke and Gertler (1995).
} 
(future) loan supply on the bank current stock prices, measures of the bank fundamentals (including, e.g., contemporaneous and future dividends-per-share, a measure of bond funding conditions, and balance sheet ratios), as well as bank and country-time fixed effects. Controlling for bank fundamentals is key for our identification: it assures that the results are not driven by shifts in fundamentals, for example a rise in banks' dividend payout. Once we control for bank fundamentals, the stock price essentially differs across banks because of differences in the remuneration requested by stock investors. Moreover, note that by including country-time fixed effects, we absorb every country-specific element, including the level of interest rates (which also impact the bank's cost of equity) as well as country-wide loan demand shocks.

By running OLS, we find that bank stock prices are positively associated with loan supply, especially to households and corporations. However, it could be that banks' lending policy and banks' market valuation are simultaneously affected by shocks unobservable to us. For example, the entrance in the market of new competitors may alter the banks' lending policy as well as the banks' valuation by stock market investors. The OLS estimates may then incorrectly associate the shifts in loan supply to the shifts in the stock price.

We deal with this endogeneity challenge by using an instrumental variable. We construct one based on the fact that a bank's net worth, and thus its stock price, depend on the bank's portfolio of investments and on how this reacts to macroeconomic conditions. The intuition behind our instrument is the following: we aim at separating the changes in a bank's equity value that are due to changes in the macro-financial environment from those resulting from changes in the bank's (endogenous) behavior. To do that, we first measure the sensitivity of each bank's stock price daily returns to the daily returns of an index representing euro area nonfinancial corporations, over one-year long rolling windows. We predict for each bank and day the stock price return that the bank should experience provided the actual return of the nonfinancial corporation index and the historical sensitivity of the bank's stock price to that index. Once these predicted returns are compiled, we obtain the trajectory that each bank's stock price should have taken given the relationship with the index. We then compute the quarterly returns implied by this predicted stock price dynamics, and use them as an instrument for the actual bank stock prices. 
The validity of the constructed instrument rests on the hypothesis that the way a bank's stock price has historically reacted to the dynamics of non-financial corporations' stock prices does not have a direct impact on the bank's future loan supply. This means, in particular, that the composition of a bank's asset portfolio must not alter the investment possibilities (including the demand for loans) that a bank has in the future. We find this hypothesis plausible, especially because in our regressions we control for aggregate conditions through country-time fixed effects. In this sense, we are hypothesizing that all banks in a given country face the same investment possibilities. However, one could also argue that changes in non-financial corporations' stock prices that signal a change in corporate fundamentals may have effects on bank profitability to the extent that they affect firms' ability to repay loans. Yet, in our regressions, this effect is partialled out by directly controlling for bank fundamentals (and country-time fixed effects).

When we test the effect of the created instrument, we find that it is positively associated with the bank stock price, as expected, and the parameter estimate is strongly statistically significant. Armed with this instrument, we then assess the effect of bank stock prices on loan supply. OLS estimates are broadly confirmed. If anything, the magnitude of the effects almost doubles: every $10 \%$ increase in a bank's stock price is associated with a rise in corporate and household lending of $0.32 \%$ of the bank's total assets. For a median bank, this means an increase in the loans to corporations and households of $0.5 \%$, consisting in an amount equal to $€ 260$ million. This effect is net of changes in bank fundamentals, and of macroeconomic conditions. It is therefore substantial.

Despite being causal, these estimates do not precisely identify the mechanism through which bank stock prices affect bank loan supply. In fact, the results we obtain are, to some extent, surprising. One reason is that, unlike bond debt, equity does not need to be rolled-over. Thus, shocks that affect its cost may not affect the ability to lend as immediately as it would be in the case of bond funding. Also, to the extent that capital requirements are not binding, which is on average the case for euro area banks given the evolution of capital ratios since 2008 (see, e.g., Altavilla et al. (2019)), banks are free to fund their loans through their preferred mix of deposits, bonds, and equity. It is thus not clear why banks would not temporarily change their funding mix so as to not react at all to changes in the cost of equity. 
One reason is that changes in the bank stock price that cannot be attributed to variations in bank fundamentals may be interpreted by the bank managers as signals on what remuneration the financial market requests to the bank. In general, when the return requested by investors reduces, the bank managers should increase the stock of equity of the bank, either by issuing new equity or by retaining earnings. Conversely, when the cost of equity increases, bank managers should reduce the quantity of retained earnings and rather satisfy the requests of equity-holders by distributing more dividends. Therefore, if this mechanism is at play, we should find that following a rise in bank stock prices, the effect on loan supply is paralleled by an effect on the bank's stock of equity. At the same time, a change in the bank's cost of equity implies that the price of risk attached to the bank also changes, and this may reverberate on the cost of other safer, but not riskless, liabilities issued by the bank. In this sense, if an increase in the bank's stock price signals an overall relaxation in bank funding constraints, it should be accompanied by a reduction in the cost of bond debt, and by a consequent increase in the volume of bonds issued.

We test whether these predictions are validated by using the same empirical setting. The only difference is that we study the effect of the bank stock price on liability side variables, namely the (future) growth in either deposits, bonds, or equity, all scaled by contemporaneous total assets. We find that the stock price is positively associated with a greater stock of equity, and a greater stock of bonds issued. This corroborates the validity of the mechanism detailed above, which rests on the informativeness of bank stock prices for bank managers.

To fully characterize the mechanism, we investigate what is the effect of bank stock prices on bank bond yields. We consider granular bond yield information on 18 banks from France, Germany, Italy, and Spain, which was originally exploited by Gilchrist and Mojon (2018). We find that an increase in bank stock prices triggers a reduction in bank bond yields. All other things held constant, including bank fundamentals and aggregate conditions, a $10 \%$ rise in the stock price is associated with a reduction of $5.3 \mathrm{bps}$ in bond yields. This is further evidence on the mechanism we highlight, namely that the appreciation of a bank's stock leads to a relaxation of the bank's funding constraints.

The main contribution of this paper is to highlight that banks' equity value affects banks' 
loan supply. This means that every financial market undervaluation of bank equity can actually transmit to households and firms in the form of a lower access to credit. In this sense, the results presented in this paper are in line with those of Balduzzi et al. (2018), who show that during the financial and sovereign debt crises, decreases in banks' equity valuations, and especially increases in their CDS spreads, resulted in lower investment, employment, and bank debt for younger and smaller Italian firms. Our paper complements those results by studying the matter at the bank level and by showing that the effects are not necessarily specific to periods of crisis.

Boucinha et al. (2017) also build on a sample of euro area banks, and find similar effects of the bank cost of equity on loan supply. However, our analysis displays two key differences. First, our empirical setup employs banks' stock price as key explanatory variable (rather than estimates of banks' cost of equity) and also adds an identification strategy based on instrumental variable techniques. Second, the mechanism we highlight is not based on the regulatory capital requirements, but rather on the informativeness of bank stock prices for bank managers.

The economics literature has approached the topic of equity funding for banks especially from the point of view of the implications of capital requirements regulations. In general, tighter capital requirements are found to reduce lending (see, e.g., Aiyar et al. (2014); Gropp et al. (2018); Fraisse et al. (2019)) and to alter the monetary policy transmission (Van den Heuvel, 2002). A key element of equity is that it is scarce and expensive to obtain. In this regard, Celerier et al. (2018) studies the implications of two (quasi-) natural experiments that change the relative cost of equity vis-à-vis debt. Their results suggest that when equity becomes cheaper, banks lend more. The authors interpret this result as coming from the fact that capital regulations assign too-low capital weights to some assets (e.g., government securities) that are not necessarily less risky than loans. This creates a distortion with banks shifting away from loans. In turn, such distortion is offset when the relative cost of equity reduces.

The results of our paper corroborate the idea that lending increases when banks' cost of equity reduces. However, our interpretation does not depend on the distortions of capital requirements regulations, and this is based on the finding that the bank stock price associates positively with both lending to firms and lending to households. Household lending accounts, in large majority, for mortgages, which have a low capital weight under both Basel II and 
III. Therefore, the distortion highlighted by Celerier et al. (2018) is of a lower importance in household lending. This implies that if the underlying force was a regulatory distortion, we should rather not find any effect on household lending.

Our reading of the results is that bank managers intepret an increase in the bank stock market value as an increase in the ability to collect in particular equity funding. Indeed, we find that the consequence is both an increase in the stock of equity funding and an increase in loan supply. This mechanism is in line with Fischer and Merton (1984), who argue that managers should take advantage of irrationally low discount rates for their firms' equity by issuing stock and investing the proceeds. Barro (1990), Morck et al. (1990), Blanchard et al. (1993), and more recently Campello and Graham (2013), all examine this mechanism, but focus mainly on non-financial corporations. Our paper indicates that this mechanism is also valid for credit institutions.

The remainder of the paper is organized as follows. Section II describes the data, while Section III presents the mechanism and preliminary evidence. Section IV describes the identification strategy, and the complete empirical evidence. Section V discusses some policy implications, while Section VI concludes.

\section{Data}

The analysis we conduct is based on bank balance sheet data, financial market data, and bank bond yield data.

\section{A Bank Balance Sheet Data}

This paper primarily exploits granular statistics on euro area monetary and financial institutions (MFIs) from the ECB's Individual Balance Sheet Item (IBSI) dataset. This dataset reports bank-level information on lending to the private sector (households, non-financial corporations, and other MFIs), as well as on funding (deposits collected, outstanding bonds issued, and capital and reserves). The IBSI dataset is available with monthly frequency. A key feature 
of the IBSI dataset is that it permits a direct comparison between MFIs located in different countries: every MFI, in fact, reports its balance sheet using the same format.

We consider the information from April 2010 to June 2019. Over this period, the IBSI dataset accounts for 330 individual MFIs. This sample is biased towards larger institutions and covers about $70 \%$ of euro area MFIs' total assets. Since our interest is in deposit-taking institutions that grant loans to households and non-financial corporations, we restrict our focus to those MFIs that have some minimal activity on both lending segments and on the deposit market.

Specifically, we select banks holding at least $5 \%$ of their assets in loans to household and firms, and which have at least $1 \%$ of total assets obtained in the form of retail deposits. These filters aim at eliminating some special banks, whose business model departs from the traditional activity of a bank: for instance, banks that raise funding only on the financial market and that mainly grant loans to others banks, or banks heavily specialized in consumer finance that are funded by other banks. This leaves us with a total of about 250 banks.

We reduce the frequency of the dataset to quarterly, and take quarter end values. Our analysis considers yearly growth rates as key dependent variables. Growth rates are defined as changes in the variable of interest from quarter $t$ to quarter $t+4$ scaled by total assets at $t$. The normalization by total assets at $t$ has the advantage of directly enabling one to measure the extent to which the growth in a given variable translates into the growth of the bank balance sheet.

Despite the key dependent variables in our analysis are yearly growth rates, the dataset on which we run the regressions has quarterly frequency. This means that every shock hitting an explanatory variable at $t$ reverberates by construction on the dependent variable for exactly four quarters. As a result, regression residuals are serially correlated. We will cope with this issue by adopting a proper clustering of standard errors. Note, however, that the reduction in the frequency (from the original IBSI dataset) attenuates the severity of this issue, which would be magnified if we used instead the dataset with monthly frequency. One could think of using lower frequencies, for example yearly frequency, but this would come at the cost of losing a lot of time-series variation, which is in fact important to identify the effects of interest. 


\section{B Financial Market Data}

We collect banks' daily stock prices, earnings-per-share, dividends-per-share, and when available the Credit Default Swap (CDS) prices, via Bloomberg and Thomson Reuters. We retrieve such information for the largest banks in the euro area, for a total of 42 banks.

We expand the set of sampled banks by building on the idea that market funding is typically raised by only one bank within a banking group. The obtained funds are then allocated within the group through the internal capital market. This is in line with the literature on cross-border banks as shock propagators (see, e.g., Cetorelli and Goldberg $(2012)$ and Schnabl (2012)). Indeed, international banking groups decide their funding mix by taking into account crosscountry differences in terms of taxation and efficiency in financial services, so as to minimize their cost of capital (Gu et al., 2015).

Therefore, to the extent that one bank in our balance sheet sample belongs to a group and does not display a stock price itself, we decide to attribute it the stock price, earnings-per-share, dividends-per-share, and CDS price, of the head of the group. In this way, we are able to expand our sample to 68 listed banks (from the original 42).

\section{Bank Bond Yield Data}

We retrieve bank bond yield data on a total of 18 banks from France, Germany, Italy, and Spain. These data were originally collected by Gilchrist and Mojon (2018). The information has monthly frequency and is available at the security-level. It includes each bond's month end yield and duration. The securities in the sample are fixed-coupon, euro-denominated, noncallable, and non-guaranteed. The original sources of the data are Datastream, Dealogic, and Bloomberg.

\section{$D$ Construction Of The Datasets And Summary Statistics}

We proceed with the construction of two datasets.

The first is the result of the merger of the quarterly bank balance sheet data with the financial market data. This is done by first obtaining the average quarterly stock price, earnings-per- 
share, dividends-per-share, and CDS price, for each bank. The obtained dataset is the one on which we base most of our analysis. It runs from 2010Q2 to 2019Q2, and includes a total of 68 banks, belonging to 42 banking groups. The banks are from 12 euro area countries. The number of banks by country is unevenly distributed, from a minimum of 2 in the Netherlands to a maximum of 10 in Germany. ${ }^{2}$ The fact that our sample includes at least two banks per country in the same quarter is essential for our empirical design: It permits, in fact, to include country-time fixed effects and thus to control for every specific component affecting one country at a given point in time.

The second dataset is the result of the merger of the bank bond yield data with the dataset just created. Before the merger, we first obtain the quarterly average of the yield and of the duration for each security in the bank bond yield data. The resulting dataset is at the securitylevel, and includes the issuing bank's stock price, and other financial market variables, together with bank balance sheet variables. Also in this case, the period covered is from 2010Q2 to 2019Q2, but sampled banks are 18 banks from 4 euro area countries.

Table凹presents the summary statistics, disaggregated by type of information. On average, a bank holds $€ 180 \mathrm{Bn}$ of total assets, while at the median it holds $€ 81 \mathrm{Bn}$. This is indicative of the high right-skewness of bank size in the sample. On average, total lending accounts for about $63 \%$ of a bank's total assets, while the investment in securities is at $17 \%$. In terms of funding, a bank obtains on average $69 \%$ of its funding through deposits, $10 \%$ through bonds, and finally $10 \%$ through equity. Note that the measurement of capital used in the IBSI data does not map with Tier 1 and Tier 2 capital.

In terms of yearly growth rates, Table 1 indicates that, in the period analyzed, banks on average increase their lending to households and firms. Conversely, they reduce their lending to other MFIs, and their holdings of securities. In terms of funding, on average banks substitute bonds by issuing more deposits. Equity funding mildly increase.

\footnotetext{
${ }^{2}$ More specifically, here follow the countries considered and their number of banks included in the sample in parentheses: Austria (9), Belgium(4), Germany (10), Spain (8), France (8), Greece (4), Ireland (4), Italy (9), the Netherlands (2), Portugal (3), Slovenia (3), and Slovakia (4).
} 


\section{The Mechanism And Preliminary Evidence}

\section{A The Mechanism: From Banks' Stock Price To Loan Supply}

Stock valuation techniques, which trace back to Williams (1938), suggest that the intrinsic value of a stock is the discounted value of the expected cash dividends per share. The discounting factor is the firm's cost of equity, which is the remuneration required by market participants to invest in the firm's equity. Specifically, when dividends are assumed constant at an amount div throughout the life of the firm, the Dividends Discount Model predicts that the stock price at time 0 writes:

$$
\text { price }_{0}=\sum_{t=1}^{\infty} \frac{d i v}{\left(1+r^{E}\right)^{t}}=\frac{d i v}{r^{E}}
$$

where $r^{E}$ denotes the firm's cost of equity. Equation 1 can be particularly useful to firm managers. In fact, to the extent that they know the future dividend dynamics and observe the stock price of their firm, they can infer the return required by investors to hold the firm's equity.

Consider now the case of a bank whose managers do not expect changes in the dividend dynamics in the future but observe a rise in their bank's stock price. All other things being equal (for example, macroeconomic conditions), since the dividend stream does not modify, the rise in the stock price is not due to changes in the bank's fundamentals. Therefore, following Equation 1. the bank's managers can infer that the remuneration required by equity investors has reduced. We propose the following formalization to understand what might be the implications.

Let us consider the case of a bank that can invest only in loans, and funds itself through deposits and equity. The bank is price-taker on the loan market, where the loan rate is $r^{L}$, and in the deposit market, where the deposit rate is $r^{D} . r^{E}$ still denotes the bank's cost of equity. We assume that $r^{E}>r^{L}>r^{D}$, reflecting the ranking in the risk of each investment. Provided an amount $D$ of deposits at the bank, we ask how the cost of equity $r^{E}$ affects the extension of credit $L$ and the issuance of equity $E$.

The bank's book profit $\Pi$ equals $r^{L} L-r^{D} D$. This profit is entirely distributed to equity holders. This means that: 


$$
r^{L} L-r^{D} D=r^{E} E
$$

which has to hold under the balance sheet constraint that $L=D+E$. Note that Equation 2 can be re-written as an equation between the loan rate and the weighted-average cost of capital. Importantly, once the balance sheet constraint is taken into account, Equation 2 implies that:

$$
\frac{D}{E}=\frac{r^{E}-r^{L}}{r^{L}-r^{D}}
$$

Equation 3 characterizes how changes in $r^{E}$ influence the equity $E$ issued in the first place. To the extent that the quantity of deposits $D$ has already been chosen by depositors, Equation 3 indicates that a lower $r^{E}$ implies a greater issuance of equity. Under the balance sheet constraint stated above, this entails a greater quantity of credit extended.

In conclusion, following this basic formalization of the forces at play, we predict that when a bank's managers observe a rise in the bank's stock price that is not due to changes in the bank's fundamentals, they may interpret this as a change in the funding ability of the bank. In particular, a greater stock price implies a lower cost of equity. This should then associate with more equity issued and a greater loan supply. Our objective for the rest of the paper is to test whether this prediction is empirically validated.

\section{$B$ Graphical Analysis}

We perform a graphical analysis to provide an intuition on the association of the loan supply with the bank equity value. We produce a scatter plot of sampled banks' (log-) stock price at quarter $t$ vs. either the banks' corporate loan growth from $t$ to $t+4$, or the banks' household loan growth from $t$ to $t+4$. Preliminarily, we rescale the three variables to lie within 0 and 1 , for each bank. This means that the normalization is bank-specific and depends on the minimum and the maximum levels attained.

The resulting scatter plots appear in Figure (1) for corporate loan supply, and in Figure (2) for household loan supply. They both show that loan growth (either to corporations or households) relates positively to the (log-) stock price, especially considering the slope of the 
lines of best fit. However, the most striking evidence of this positive relationship can be obtained by looking at the heatmaps of the two scatter plots, which are reported on the right of each figure. They both indicate that the mass of points distribute especially over a region, depicted in red, whose shape has a "positive slope".

These preliminary results are in line with our formalization presented above: a higher stock price associates with a greater loan supply. However, these results are only partial evidence of the mechanism, as we do not control for bank fundamentals. We thus provide a formal econometric model to test the existence of the mechanism we hypothesize.

\section{Econometric Model}

Our objective is to assess whether changes in a bank's stock price that are not due to changes in the bank's fundamentals affect the bank's loan supply. The constructed panel dataset on euro area banks can serve this purpose as it allows us to match banks' loan supply with their stock price and fundamentals. Our main specification writes:

$$
\frac{\Delta \text { loans }_{j ; t \rightarrow t+4}}{\text { assets }_{j ; t}}=\beta \text { log stock price } j ; t+\text { controls }_{j ; t}+\eta_{c_{j} ; t}+\eta_{j}+\eta_{j ; t}
$$

where $\frac{\Delta \text { loans }_{j ; t \rightarrow t+4}}{\text { assets }_{j ; t}}$ is our measure of loan supply, and denotes the loan growth from quarter $t$ to quarter $t+4$ for bank $j$, scaled by the bank's total assets at $t$.

As discussed above, a crucial element for the identification of the mechanism is to control for each bank's fundamentals. This is the role of controls $_{j ; t}$, which include several bank-quarter level variables: The (log-) dividends-per-share at $t$ and (log-) dividends-per-share at $t+4$, which measure the contemporaneous and future amounts of cash dividends paid by the bank. The (log-) earnings-per-share at $t$ and (log-) earnings-per-share at $t+4$, which proxy for the bank's contemporaneous and future profitability. The $\left(\log _{-}\right)$CDS price at $t$, which is a measure of the remuneration required to the bank on the bond market. The (log-) total assets at $t$, which is a measure of bank size. The loans-to-assets ratio, capital-to-assets ratio, and deposits-toassets ratio, all at $t$, which proxy for the asset and liability structure of the bank. Finally, the non-financial-assets ratio at $t$, which is a measure of the importance of intangibles in the 
bank's balance sheet. ${ }^{3}$ As discussed above, in case the bank does not display financial market information, we attribute it that of the head of the group.

Besides controls $s_{j ; t}$, Equation 4 includes $\eta_{c_{j} ; t}$, which are country-time fixed effects. These control for all country-time specific elements, for example the level of the sovereign interest rates, the country business cycles, and the country risk. $\eta_{j}$ are bank fixed effects, which absorb every bank-specific time-invariant characteristic, such as the bank's business model, the location of branches, and the type of services offered (of course, for the components of these characteristics that do not change over time).

The main parameter of interest of Equation 4 is $\beta$. It traces the impact of banks' (log-) stock price on their loan supply. Since we control for bank fundamentals (through controls $s_{j ;}, \eta_{c_{j} ; t}$, and $\left.\eta_{j}\right), \beta$ captures the effect of changes in the bank stock price that are not due to changes in the bank fundamentals. Consider, for example, the case in which a bank experiences an increase in its profitability and pays more dividends. Even if this reflects on the bank's stock price and also on loan supply, this second effect is absorbed by controls $s_{j ; t}$, and does not contribute to the identification of $\beta$. If, instead, fundamentals do not change while the stock price does, $\beta$ traces the impact of such stock price change on the bank's loan supply. Therefore, a statistically significant and positive $\beta$ would suggest that bank managers take an increased stock price as a signal of an easing in the bank's funding conditions, and react by supplying more loans.

Another important thing to note of Equation 4 is that it saturates our panel with a large set of fixed effects. As said, country-time fixed effects control for every country specific dynamics, for example aggregate loan demand cycles. Therefore, under the hypothesis that all banks based in a country face similar potential borrowers, these fixed effects serve us to control for loan demand. This implies that the estimated $\beta$ will be net of demand effects. Furthermore, the inclusion of this set of fixed effects implies that $\beta$ is estimated by comparing banks within the same country which experience different deviations in their stock price. Importantly, our sample includes banks related to cross-border banking groups. Banks within the same group display the same stock price, but experience different country-specific shocks. Thus, particularly

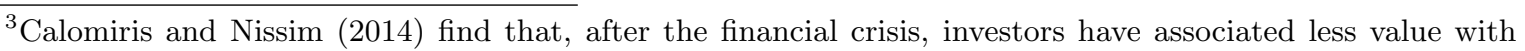
banks' intangibles and this has reflected on their market-to-book ratios: in our case, this implies that a bank with more intangibles is expected to be less able to lend to the economy. 
in those cases, country-time fixed effects absorb country-specific components whose impact on lending could otherwise be incorrectly attibuted to stock prices.

\section{OLS Estimates}

We bring Equation 4 to the data, and investigate the effect of banks' stock price on banks' loan supply to corporations, households, and other MFIs. Note that, in our setting, a shock happening at quarter $t$ impacts the dependent variable for four quarters, that is from quarter $t$ to quarter $t+3$. This is because we measure loan supply through one-year ahead loan growths, which given the quarterly frequency of the sample thus overlap with each other. We account for serial correlation in the errors by clustering standard errors at the level of each banking group. This also allows us to correct the estimated standard errors for possible correlation in the errors across banks belonging to the same group. Results appear in Table II]

Columns (1), (4), and (7) present the effects including only bank fixed effects. We add to them country-time fixed-effects in columns (2), (5) and (8): the identification is now across banks within the same country. Columns (3), (5) and (9) include the complete set of control variables, and thus absorb changes in bank fundamentals. All columns point to a positive association of the stock price with loan supply. However, the effects are statistically significant mainly with corporate and household lending.

Overall, these results corroborate the prediction derived from the simple formalization presented at the beginning of this section: stock price changes that are not due to changes in the bank fundamentals are used by bank managers as information on the return required by equityholders. An increase in the stock price implies a lower cost of equity. The resulting relaxation of the bank's funding constraints enable the bank to provide more credit to the economy.

These OLS results have one important limitation. It could be that our set of control variables misses some potentially important determinant of bank loan supply, for example the entrance in the market of new competitors. This may lead the financial market to change the forecasts of future bank fundamentals, and consequently of the bank equity value. Our measures of future fundamentals (taken at $t+4$ ) control for the future actual fundamentals. However, if the actual fundamentals do not change while investors (over-) react to an element that is unobservable to 
us, and which simultaneously affects loan supply, OLS estimates may incorrectly attribute the change in loan supply to the change in stock price. Overall, this suggests that the inability to control for unobservable factors influencing loan supply and bank stock prices makes the stock price endogenous, and OLS estimates not causal. The following section provides a instrumental variables strategy to cope with this endogeneity issue.

\section{Instrumental Variable Strategy And Complete Empirical Analysis}

\section{A Instrumental Variable Strategy}

The detailed endogeneity issue questions the validity and causality of our OLS estimations. Endogeneity makes OLS estimates biased. We deal with this issue by using an instrumental variable strategy. The idea is to find a plausibly exogenous shifter for bank stock prices, and measure the effect of interest due to the part of stock prices that is due to such shifter.

In general, the value of a bank's stock depends on the bank's net worth, which in turn reflects the bank's portfolio of investments. Importantly, the composition of every bank's portfolio of investments is unique, and therefore reacts differently to macroeconomic conditions. ${ }^{4}$ Such relationship is not only heterogeneous across banks, but also shows persistance for the same bank over time. We exploit this idea to construct a bank-time specific instrument.

The Euro STOXX ex Financials Index (SXXGNFT) represents the stock price dynamics of large, mid and small capitalisation companies of 11 Euro area countries: Austria, Belgium, Finland, France, Germany, Ireland, Italy, Luxembourg, the Netherlands, Portugal and Spain. Importantly, this index is not based on the stocks of financial companies. It is rather an aggregate representation of the stock price dynamics of non-financial corporations in the euro area.

We collect the daily values of the Euro STOXX ex Financials Index from 2009 to 2019, and compute the daily returns. We merge this information with the panel of sampled head-ofthe-banking-group's daily stock prices. We compute daily stock returns and, for each head-ofthe-banking-group separately, we regress such returns on the Euro STOXX ex Financials Index

\footnotetext{
${ }^{4}$ For example, bank $a$ may have financed one industry more than bank $b$. To this extent, a shock hitting that industry in particular will have greater effect on the value of the portfolio of bank $a$.
} 
returns over one-year long rolling windows. The idea is to measure, for each group over time, how much of its stock returns depend on the index returns.

These regressions deliver banking-group-day specific estimates of the relationship existing between the stock price and the index over the preceding year. Based on these estimates, we predict for each banking group and day the stock price return that the banking group should experience provided the realized return of the Euro STOXX ex Financials Index. Then, for each banking group, we take the actual stock price at the beginning of the stock price series (in most cases, January 2, 2009), and add to it the compiled returns we just predicted. We plot the resulting predicted dynamics vis-à-vis the actual dynamics for four representative banks in Figure 3. The two time-series are closely related, but not one-to-one. The difference between the two series reflects all factors influencing the stock price besides the Euro STOXX ex Financials Index.

Once we have constructed these predicted dynamics, we compute the quarterly returns. Such returns will then be the instrument for the bank stock prices in our baseline model. Overall, this instrument reflects how each banking group's stock price reacts to the dynamics of non-financial corporations' stock prices. Its validity lies in the plausible hypothesis that the historical sensitivity of a bank's portfolio to the Euro STOXX ex Financials Index does not have a direct impact on the bank's future investment decisions. This means, in particular, that the composition of a bank's asset portfolio must not alter the investment possibilities, including the demand for loans, which a bank has in the future. We find this hypothesis plausible, in particular because in our regressions we control for aggregate conditions through country-time fixed effects. In this sense, we are hypothesizing that all banks in a given country face the same investment possibilities.

Note that changes in non-financial corporations' stock prices may be due to changes in non-financial corporations' fundamentals, and hence ability to repay loans. This suggests that changes in non-financial corporations' stock prices may in turn affect bank profitability and fundamentals. Our empirical model includes measures of each bank's fundamentals as control variables, and therefore controls for such spillovers from non-financial corportations to banks. As a consequence, only part of the changes in non-financial corporations' stock prices serve as 
instrument for banks' stock prices, and this is essentially the part that does not reflect changes in the non-financial corporations fundamentals.

We check the strength of the constructed instrument by regressing bank stock prices on predicted returns, controls $s_{j, t}$, as well as country-time and bank fixed effects. Effectively, this regression corresponds to the first-stage of the Two-Stage least squares we implement below. The results are presented in Table III. The first column presents the effect including only the predicted return and bank fixed effects, while the second column also adds country-time fixed effects. The third column excludes the predicted return from the regression but includes the full set of controls. Finally, the fourth column presents the estimation results including the predicted return and all controls.

As expected, we find that the predicted return is positively associated with the bank stock price, with a strong statistical significance. This indicates the strength of the proposed instrumental variable. The reason why we exclude the predicted return from the list of regressors in the third column is to check whether our instrument is the only cause of the high $R^{2}$, which would be suspicious. The third column displays a high $R^{2}$, similar to all other columns, indicating that such high level is mostly due to our set of controls and in particular to the fixed effects, rather than to the predicted return.

\section{$B$ Instrumental Variable Results}

Armed with the instrument just described, we assess whether changes in bank stock prices that are not due to changes in bank fundamentals affect bank loan supply. The estimated effects appear in Table IV, where standard errors are clustered at the banking group level.

The IV estimation broadly confirms the OLS estimation. A rise in the stock price translates into greater loan supply especially to corporations and households. If anything, relative to OLS estimates, the magnitude of the effects changes and almost doubles: every $10 \%$ increase in a bank's stock price is associated with a rise in corporate and household lending of $0.32 \%$ of the bank's total assets. For a median bank, this means an increase in the loans to corporations and households of $0.5 \%$, consisting in an amount equal to $€ 260$ million. This effect is net of 
changes in bank fundamentals, including changes in funding cost on the bond market (which we measure by the log- CDS price), and country-time dynamics.

The (log-) stock price is also positively associated with lending to other MFIs, and investment in securities. However, in these cases, the parameter estimates are not statistically significant at conventional levels. Also, we find that the overall size of the bank is affected by the nonfundamental changes in the bank's stock price: a $10 \%$ increase in the stock price is associated with an increase of the bank's total assets of $0.65 \%$.

The proposed instrument is not weak: the reported F-statistic is well above the rule-of-thumb threshold of F = 10 indicated by Staiger and Stock (1997). Under the plausible identification hypothesis that the composition of a bank portfolio does not affect the bank's loan supply in the future, the IV estimates can then be taken as causal. They indicate that bank managers take changes in the bank's stock price that are not caused by changes in the bank fundamentals as information about the remuneration required by equity-investors. A positive change in the bank stock price relaxes the bank's funding constraints, and results in greater lending.

Clearly, the highlighted mechanism should also be visible on the bank liability side: in accordance with the predictions of the stylized framework of Section [II] a reduction in the bank's cost of equity should result in more loan supply to the extent that the bank increases its stock of equity. To find complete confirmation of the mechanism, we thus investigate how the bank stock price impacts the bank stock of equity.

\section{Confirmation Of The Mechanism: How The Stock Price Impacts The Liability Side}

We check whether banks' stock price impacts banks' outstanding volume of equity by exploiting our baseline Equation 4 . The only difference relative to the analysis conducted above is that we take as dependent variable the change in capital and reserves from $t$ to $t+4$ normalized by total assets at $t$.

In principle, when the price of risk attached to a bank changes, this change has a first impact on the bank's cost of equity, as equity is the riskiest liability that a bank can issue. However, the same change may reverberate on the cost of other safer, but not riskless, liabilities. In this sense, an increase in the stock price may trigger a reduction in the cost of bond debt, and 
correspondingly an increase in bond issuance. To understand if this is the case, we consider as dependent variables also the normalized change in securities issued (i.e., bonds), and in deposits.

We exploit the same instrumentation strategy, and cluster standard errors at the banking group level. Results appear in Table $\mathrm{V}$. We find confirmation of the mechanism: an increase in banks' stock price triggers an increase in banks' stock of equity, and also an increase in bond issuance. Every $10 \%$ increase in the stock price, the volume of equity raises by $0.11 \%$ of total assets, and the volume of bond funding by $0.17 \%$ of total assets. For a bank at the median for total assets, this corresponds to a greater volume of equity of $€ 89$ million, and to $€ 138$ million of more bonds issued.

Contrarily to the cost of equity, the cost of bond debt is observable. We can thus assess whether the reason why banks issue bonds to a greater extent is that the increase in the stock price is associated with a reduction in bond yields. To do so, we exploit the second dataset constructed in the Data section. The dataset is a panel of bonds issued by banks from France, Germany, Italy, and Spain, which reports the bond yield, the bond duration, as well as bankspecific financial market and balance sheet information, with quarterly frequency.

The econometric model we bring to the data relates the effective yield of an outstanding bank bond in a given quarter to the bank (log-) stock price, the bond duration, the (log-) earnings-pershare, (log-) dividends-per-share, (log-) earnings-per-share at $t+4,(\log -)$ dividends-per-share at $t+4$, as well as bank balance sheet controls ((log-) total assets, loans-to-assets ratio, nonfinancial-assets ratio, capital-to-assets ratio, and deposits-to-assets ratio). We also add countrytime fixed effects and bond fixed effects, which absorb time-invariant bond characteristics such as the coupon rate.

Table VI] presents the OLS estimates, together with the IV estimates, in which we exploit our instrumentation strategy. Standard errors are clustered at the bond level. We find that an increase in bank stock prices triggers a reduction in bank bond yields. All other things held constant, including bank fundamentals and aggregate conditions, a $10 \%$ rise in the stock price is associated with a reduction of 5.3 bps in bond yields, according to the IV estimates in column (3). This is further evidence on the mechanism we highlight about an overall relaxation of funding constraints following the appreciation of banks' stock. 
To conclude, this subsection displays causal estimates on how changes in bank stock prices, which do not depend on changes in bank fundamentals, trigger changes in bank funding ability. Not only they alter bank equity funding conditions, but they also impact the price at which the bank can borrow on the bond market, and consequently the quantity of bonds that the bank issues.

\section{Policy Implications}

The results obtained in our empirical analysis indicate the existence of a causal link between bank equity value and bank loan supply. The mechanism we highlight rests on the idea that bank managers take the stock market value of their bank as an important indication of what the market expects as remuneration to invest in the equity of the bank, and react accordingly. It seems then interesting to adopt a macroeconomic point of view for the implications that this mechanism may have in aggregate.

Figure 4 plots the time-series dynamics of the Euro STOXX Index (SXXGT) and of the Euro STOXX Banks Index (SX7GT). The first index captures the stock price dynamics of euro area large, mid and small capitalisation companies (including banks), while the second index the stock price dynamics of euro area banks only. It is remarkable that there is a break in the behavior of the two indices: until mid-2010 the two indices closely co-move, with the Euro STOXX Banks displaying a more volatile trajectory; after that time, the co-movement is broken, and while the Euro STOXX Index has considerably appreciated since mid-2010, the Euro STOXX Banks Index has stalled at the initial level and has even depreciated since then.

The break of mid-2010 corresponds to the eruption of the European sovereign debt crisis. It could then be argued that such break is mostly due to the continued worsening of bank fundamentals. In order to check whether this is the case, we obtain industry-specific information on the return on equity and dividend payout ratio for European firms from 2011 to 2017 from Aswath Damodaran's website. The data span across all industries, and are therefore useful 
to produce a cross-industry analysis. ${ }^{5}$ In particular, this information is useful to understand whether banks experience a considerable differential trend in profitability since 2011 and/or they have decided to distribute less cash dividends.

Figure 5 presents the dynamics of the return on equity comparing all firms with banks only, while Figure 6 repeats the exercise with the dividend payout ratio. If anything, banks have increased their profitability over time, and display payout ratios similar to all firms. Most importantly, the two figures do not display differential trends between banks and other firms such to justify the differential trend in the indices appearing in Figure 4 .

Of course, the information contained in Figures 5 and 6 is only partial, and we cannot definitely conclude on the dynamics of banks' fundamentals. Nonetheless, the figures presented seem to suggest that the considerably inferior dynamics of euro area banks' stock prices (relative to that of non-financial corporations) is not grounded on a differential in the dynamics of their fundamentals.

Building on the results presented in previous sections, euro area bank managers may have inferred that equity investors have required since 2011 a greater remuneration to hold bank equity. They may have thus reacted by lending less that they would have done without such trend in the required remuneration. Of course, we can provide only suggestive evidence on this matter. Nonetheless, the mechanism we highlight together with this suggestive evidence gives ground to the continued effort by the ECB to sustain euro area banks' loan supply.

\section{Conclusion}

This paper studies how bank stock prices affect loan supply. We exploit granular balance sheet data on 68 Euro area banks from 12 euro area countries, matched with financial market information including bank stock prices, earnings-per-share, dividends-per-share, and CDS prices. The period of analysis is from 2010Q2 to 2019Q2.

\footnotetext{
${ }^{5}$ The banking industry is splitted into 'Bank (Money Center)' and 'Banks (Regional)'. We compute overall banking industry figures as weighted averages of the figures of the two sub-industries, with the number of banks in each sub-industry being the weight.
} 
Our findings indicate that increases in bank stock prices that are not due to changes in bank fundamentals cause greater lending and banks to increase their stock of equity. These findings suggest that bank managers exploit stock prices to infer their bank's cost of equity, and increase lending and equity funding when the cost of equity reduces.

We also show that euro area non-financial corporations and banks have experienced a considerable divergence in stock price dynamics since mid-2010, which is not grounded on a difference in the trends of the fundamentals. The mechanism we highlight suggests that such undervaluation of euro area banks may have resulted in a bank loan supply lower than it could otherwise realize. 


\section{References}

Aiyar, Shekhar, Charles W Calomiris, and Tomasz Wieladek, "Does macro-prudential regulation leak? Evidence from a UK policy experiment," Journal of Money, Credit and Banking, 2014, 46 (s1), 181-214.

Altavilla, Carlo, Desislava Andreeva, Miguel Boucinha, and Sarah Holton, "Monetary policy, credit institutions and the bank lending channel in the euro area," ECB Occasional Paper, 2019, (222).

Balduzzi, Pierluigi, Emanuele Brancati, and Fabio Schiantarelli, "Financial markets, banks cost of funding, and firms decisions: Lessons from two crises," Journal of Financial Intermediation, 2018, 36, 1-15.

Barro, Robert J, "The stock market and investment," The review of financial studies, 1990, $3(1), 115-131$.

Bernanke, Ben S and Alan S Blinder, "Credit, Money, and Aggregate Demand," American Economic Review, 1988, 78 (2), 435-439.

- and Mark Gertler, "Inside the black box: the credit channel of monetary policy transmission," Journal of Economic perspectives, 1995, 9 (4), 27-48.

Blanchard, Olivier, Changyong Rhee, and Lawrence Summers, "The stock market, profit, and investment," The Quarterly Journal of Economics, 1993, 108 (1), 115-136.

Boucinha, Miguel, Sarah Holton, and Andrea Tiseno, "Bank equity valuations and credit supply," Working Paper, 2017.

Calomiris, Charles W. and Doron Nissim, "Crisis-related shifts in the market valuation of banking activities," Journal of Financial Intermediation, 2014, 23 (3), 400 - 435.

Campello, Murillo and John R Graham, "Do stock prices influence corporate decisions? Evidence from the technology bubble," Journal of Financial Economics, 2013, 107 (1), 89110.

Celerier, Claire, Thomas K Kick, and Steven Ongena, "Taxing bank leverage: The effects on bank capital structure, credit supply and risk-taking," Working Paper, 2018.

Cetorelli, Nicola and Linda S. Goldberg, "Banking Globalization and Monetary Transmission," The Journal of Finance, 2012, 67 (5), 1811-1843.

den Heuvel, Skander J. Van, "The bank capital channel of monetary policy," Working Paper, 2002.

Fischer, Stanley and Robert C. Merton, "Macroeconomics and finance: The role of the stock market," Carnegie-Rochester Conference Series on Public Policy, January 1984, 21 (1), $57-108$.

Fraisse, Henri, Mathias Lé, and David Thesmar, "The real effects of bank capital requirements," Management Science, 2019. 
Gilchrist, Simon and Benoit Mojon, "Credit risk in the euro area," The Economic Journal, 2018, 128 (608), 118-158.

Gropp, Reint, Thomas Mosk, Steven Ongena, and Carlo Wix, "Banks response to higher capital requirements: Evidence from a quasi-natural experiment," The Review of Financial Studies, 2018, 32 (1), 266-299.

Gu, Grace Weishi, Ruud de Mooij, and Tigran Poghosyan, "Taxation and leverage in international banking," International Tax and Public Finance, 2015, 22 (2), 177-200.

Morck, Randall, Andrei Shleifer, and Robert W. Vishny, "The stock market and investment: is the market a sideshow?," Brookings papers on economic Activity, 1990, 1990 (2), 157-215.

Schnabl, Philipp, "The international transmission of bank liquidity shocks: Evidence from an emerging market," The Journal of Finance, 2012, 67 (3), 897-932.

Staiger, Douglas and James H. Stock, "Instrumental Variables Regression with Weak Instruments," Econometrica, 1997, 65 (3), 557-586.

Williams, John Burr, The Theory of Investment Value, Harvard University Press, 1938. 


\section{Figures}

\section{Figure 1}

Corporate loan supply vs. bank (log-) stock price

This figure plots the scatter plot (left) and heatmap (right) of banks' loan supply to non-financial corporations vs. their own log- stock price. In the heatmap, the scale is blue:green:yellow:red, with blue denoting a low concentration of observations and red a high concentration of observations.

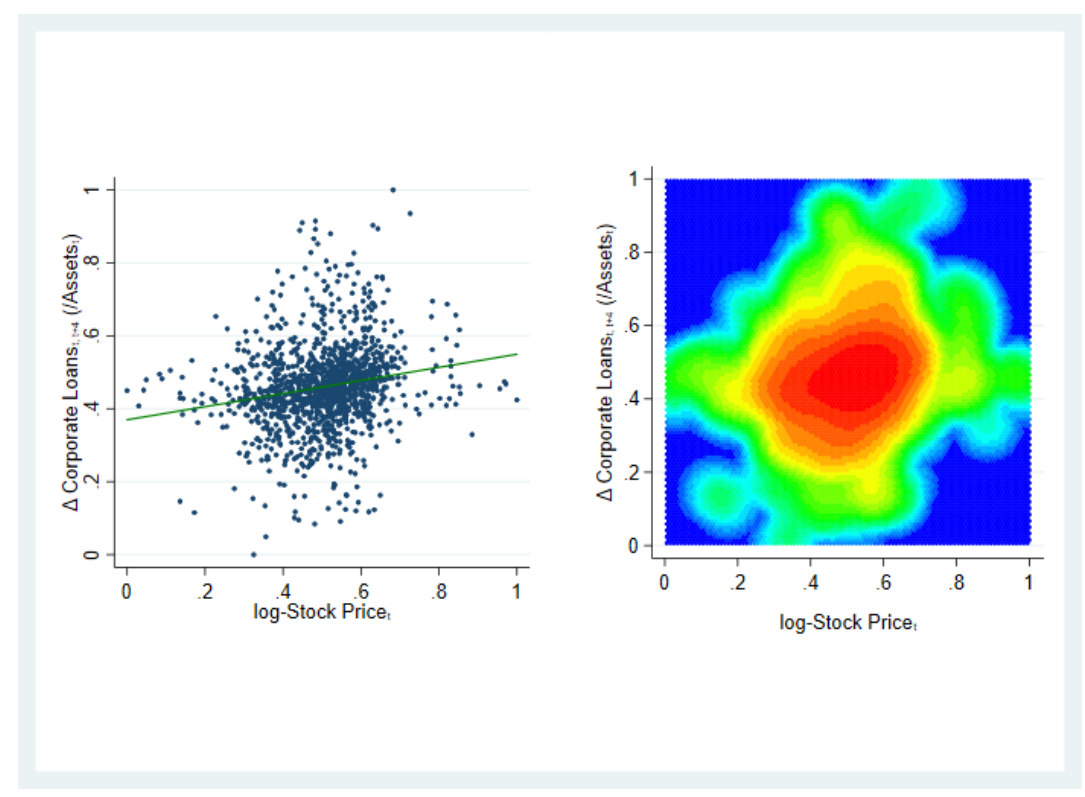

Figure 2

Household loan supply vs. bank (log-) stock price

This figure plots the scatter plot (left) and heatmap (right) of banks' loan supply to households vs. their own log- stock price. In the heatmap, the scale is blue:green:yellow:red, with blue denoting a low concentration of observations and red a high concentration of observations.
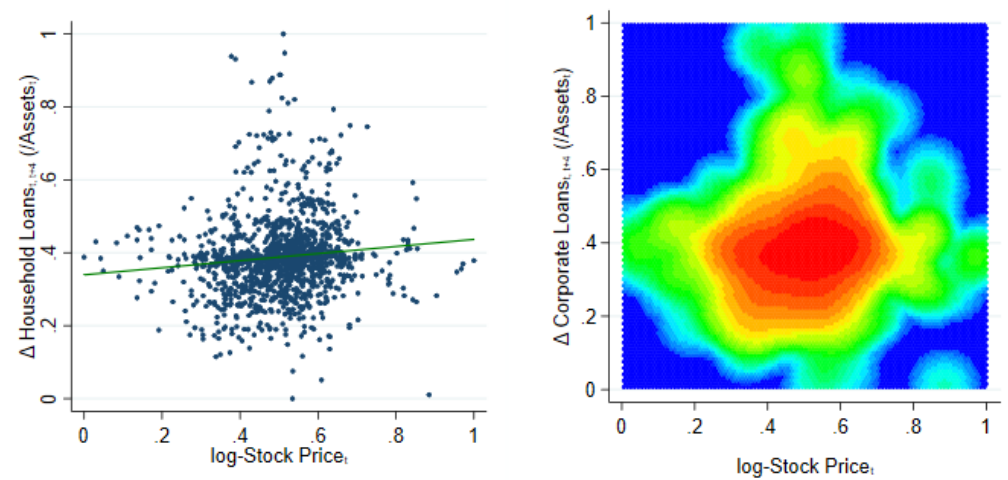
Figure 3

Actual and predicted stock prices

This figure plots the time-series of actual and predicted daily stock prices of four selected banks, from 2010Q1 to 2019 Q2.
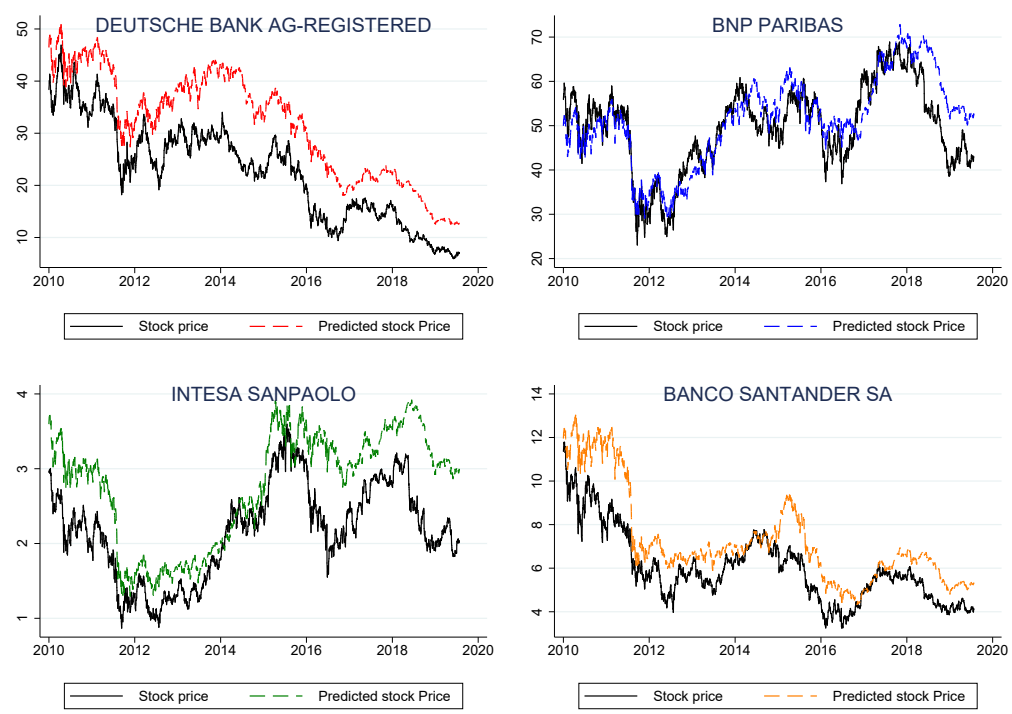

Figure 4

Euro STOXX vs. Euro STOXX Banks

This figure plots the time-series of the daily Euro STOXX (SXXGT) and Euro STOXX Banks (SX7GT), from $2010 \mathrm{Q} 1$ to 2019Q2.

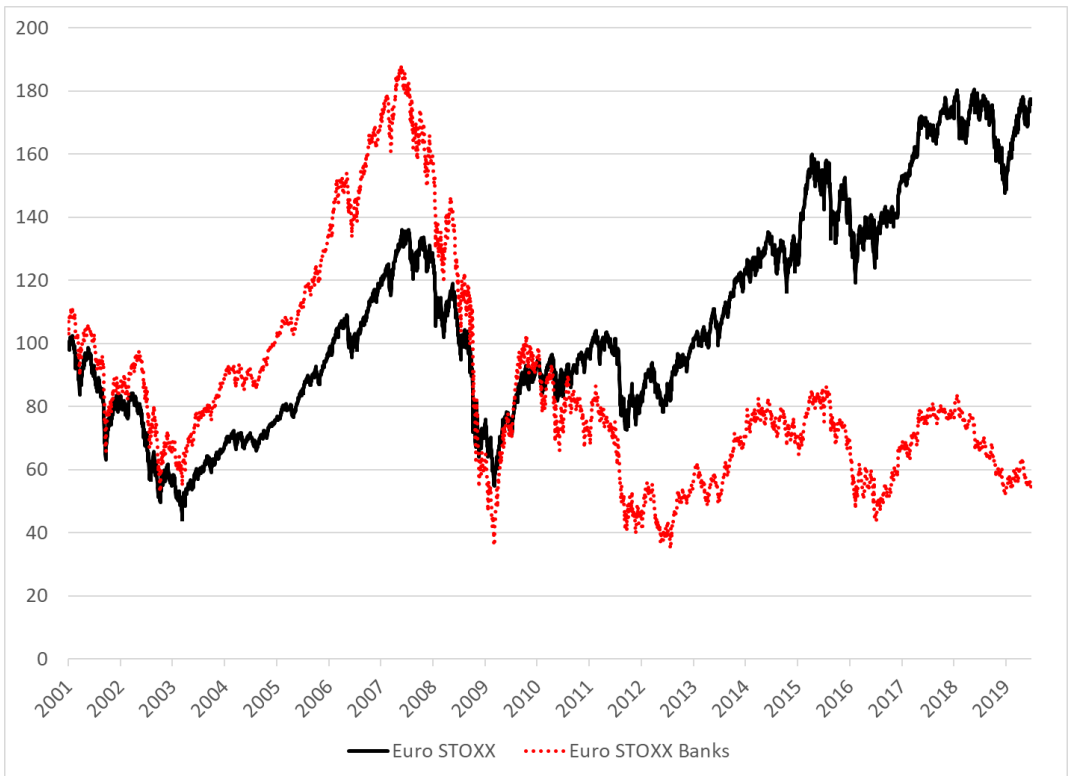


Figure 5

Return on equity: all firms vs. banks

This figure plots the time-series of the return on equity of all firms and of banks only, in Europe. Source: Aswath Damodaran's website.

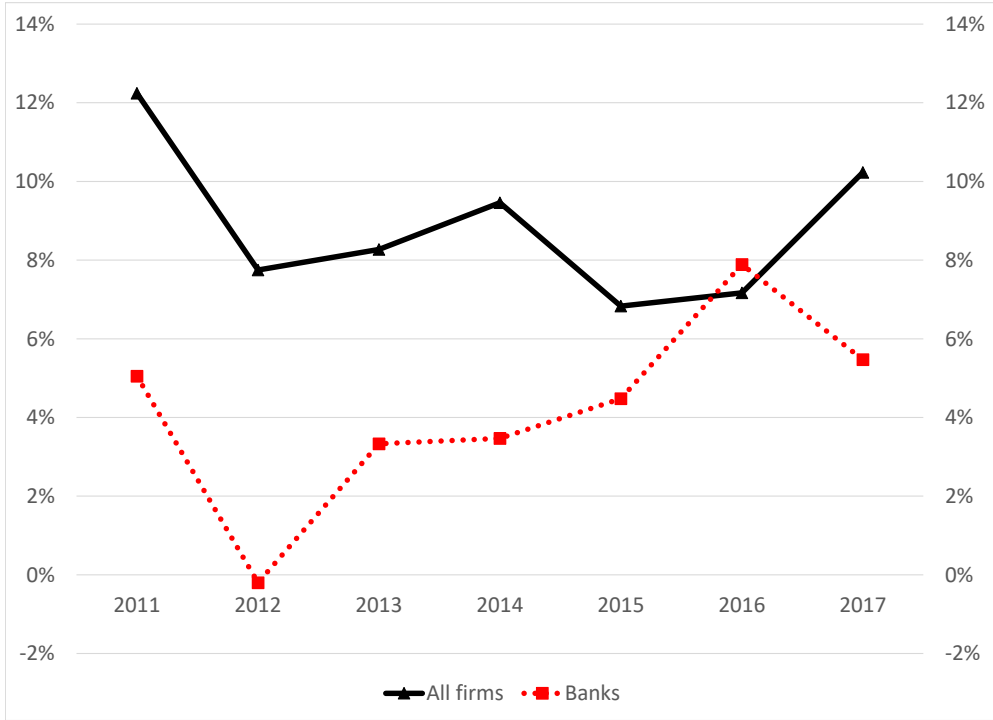

Figure 6

Dividend payout ratio: all firms vs. banks

This figure plots the time-series of the dividends payout ratio of all firms and of banks only, in Europe. Source: Aswath Damodaran's website.

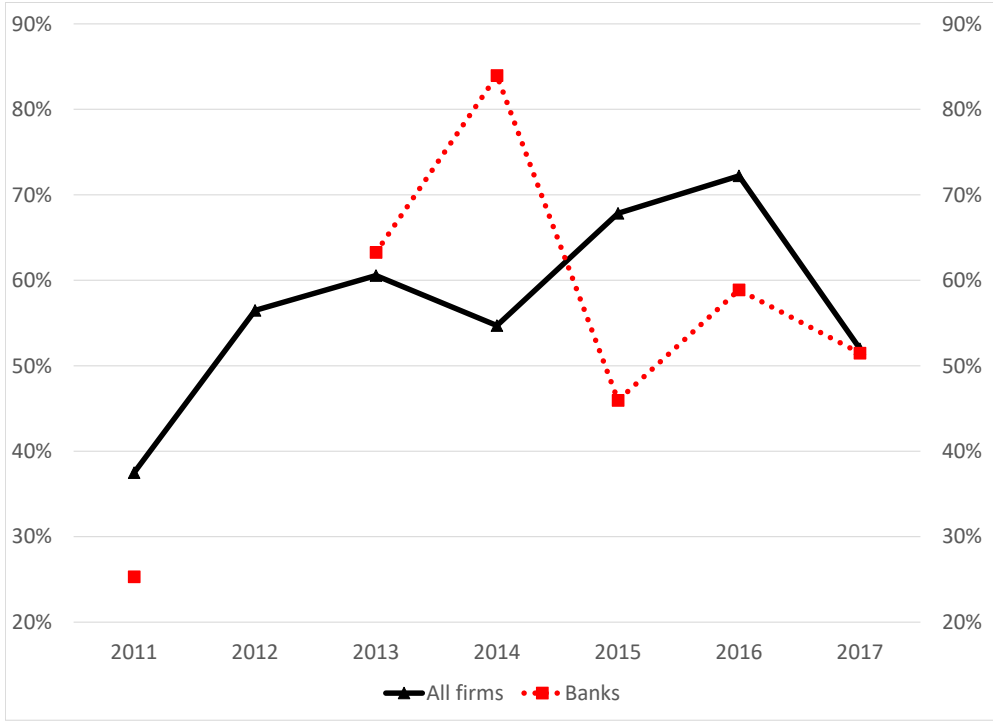




\section{Tables}

Table I

\section{Summary statistics}

This table presents the summary statistics of the data considered in our analysis. The first dataset refers to financial market information, and is available for each head of banking group. It is collected via Bloomberg and Thomson Reuters. The second dataset refers to balance sheet information of each bank included in the ECB's IBSI database. Finally, the third dataset includes information on bond yields of banks headquartered in France, Germany, Italy, or Spain (and present in the IBSI database). It is a subset of the database collected by Gilchrist and Mojon (2018). The period of observation is from 2010Q2 to 2019Q2, and the frequency is quarterly.

\begin{tabular}{|c|c|c|c|c|c|c|c|}
\hline & N. obs. & N. banks & Mean & St. Dev. & p10 & p50 & p90 \\
\hline \multicolumn{8}{|l|}{ Financial Market Information } \\
\hline$(\log -)$ Stock Price $t$ & 792 & 42 & 2.4 & 1.8 & 0.6 & 2.1 & 4.0 \\
\hline (log-)Earnings per Share Sh & 792 & 42 & 0.7 & 1.4 & 0.0 & 0.2 & 1.7 \\
\hline (log-)Dividend per Share $_{t}$ & 792 & 42 & -0.4 & 0.7 & -1.0 & -0.5 & 0.2 \\
\hline$(\log -) \mathrm{CDS}_{t}$ & 792 & 42 & 2.2 & 2.5 & 0.0 & 0.0 & 5.1 \\
\hline \multicolumn{8}{|l|}{ Balance Sheet Information } \\
\hline Total Assets $_{t}(\mathrm{Bns})$ & 1,367 & 68 & 180.0 & 236.5 & 11.0 & 81.3 & 527.0 \\
\hline $\operatorname{Loans}_{t}\left(/ \operatorname{Assets}_{t}\right)$ & 1,367 & 68 & 63.4 & 12.8 & 45.3 & 64.3 & 79.9 \\
\hline Securities held (/Assets) & 1,367 & 68 & 16.8 & 10.1 & 5.6 & 16.4 & 29.1 \\
\hline Non-Financial Assets $t$ (/Assets $t)$ & 1,367 & 68 & 0.8 & 0.9 & 0.1 & 0.6 & 1.9 \\
\hline Capital and Reserves $t$ (/Assetst) & 1,367 & 68 & 10.0 & 5.3 & 3.9 & 9.9 & 17.4 \\
\hline $\operatorname{Deposits}_{t}\left(/\right.$ Assets $\left._{t}\right)$ & 1,367 & 68 & 68.8 & 11.0 & 56.9 & 70.1 & 81.8 \\
\hline Securities issued $_{t}\left(/\right.$ Assets $\left._{t}\right)$ & 1,367 & 68 & 10.4 & 8.2 & 0.2 & 9.3 & 21.8 \\
\hline$\Delta$ Corporate Loans $t, t+4\left(/\right.$ Assets $\left._{t}\right)$ & 1,367 & 68 & 0.3 & 1.5 & -1.7 & 0.2 & 1.8 \\
\hline$\Delta$ Household Loans $t, t+4\left(/\right.$ Assets $\left._{t}\right)$ & 1,367 & 68 & 0.5 & 1.3 & -0.7 & 0.2 & 2.6 \\
\hline$\Delta$ MFI Loans $_{t, t+4}\left(/\right.$ Assets $\left._{t}\right)$ & 1,367 & 68 & -0.4 & 1.4 & -2.0 & -0.1 & 0.8 \\
\hline$\Delta$ Securities $_{t, t+4}\left(/\right.$ Assets $\left._{t}\right)$ & 1,367 & 68 & -1.0 & 1.7 & -4.3 & -0.7 & 0.6 \\
\hline$\Delta$ Total Assets $_{t, t+4}\left(/\right.$ Assets $\left._{t}\right)$ & 1,367 & 68 & 0.1 & 4.1 & -5.2 & 0.4 & 4.9 \\
\hline$\Delta \operatorname{Deposits}_{t, t+4}\left(/\right.$ Assets $\left._{t}\right)$ & 1,367 & 68 & 0.8 & 3.7 & -3.5 & 1.1 & 5.6 \\
\hline$\Delta$ Securities issued $_{t, t+4}\left(/\right.$ Assets $\left._{t}\right)$ & 1,367 & 68 & -0.6 & 1.5 & -2.7 & -0.1 & 0.5 \\
\hline$\Delta$ Capital and Reserves $t, t+4$ (/Assets $t)$ & 1,367 & 68 & 0.1 & 0.6 & -0.4 & 0.1 & 0.7 \\
\hline \multicolumn{8}{|l|}{ Bond Yield Information } \\
\hline Bond Yield $_{t}$ & 6,293 & 18 & 2.2 & 1.4 & 0.5 & 1.8 & 4.1 \\
\hline Bond Duration $_{t}$ & 6,293 & 18 & 3.7 & 1.0 & 2.3 & 3.6 & 5.1 \\
\hline
\end{tabular}


Table II

The effect of the bank stock price on bank loan supply: OLS estimates

This table presents the OLS estimates of the effect of banks' (log-) stock price on their loan supply and investment in securities. The panel runs from 2010Q2 to 2019Q2. The dependent variables are the difference, scaled by total assets, of, respectively, loans to non-financial corporations in columns (1) to (3), loans to households in columns (4) to (6), loans to monetary and financial institutions in columns (7) to (9), and securities held in columns (10) to (12). 'Financial Market Controls' include the (log-) earnings-per-share, (log-) dividends-per-share, $(\log -)$ CDS price, $(\log$-) earnings-per-share at $t+4$, and (log-) dividends-per-share at $t+4$. 'Balance Sheet Controls' comprise the (log-) total assets, loans-to-assets ratio, non-financial-assets ratio, capital-to-assets ratio, and deposits-to-assets ratio. Stock prices, earnings per share, dividends

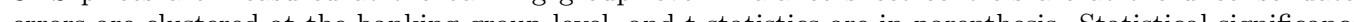
${ }^{*} p<0.10,{ }^{* *} p<0.05,{ }^{* * *} p<0.01$

\begin{tabular}{|c|c|c|c|c|c|c|c|c|c|c|c|c|}
\hline \multicolumn{13}{|l|}{ Dependent Variable: } \\
\hline & \multicolumn{3}{|c|}{$\Delta$ Corporate Loans $_{t, t+4}\left(/\right.$ Assets $\left._{t}\right)$} & \multicolumn{3}{|c|}{$\Delta$ Household Loans $_{t, t+4}\left(/\right.$ Assets $\left._{t}\right)$} & \multicolumn{3}{|c|}{$\Delta$ MFI Loans $t, t+4\left(/\right.$ Assets $\left._{t}\right)$} & \multicolumn{3}{|c|}{$\Delta$ Securities $_{t, t+4}\left(/\right.$ Assets $\left._{t}\right)$} \\
\hline & $(1)$ & $(2)$ & (3) & $(4)$ & $(5)$ & (6) & $(7)$ & $(8)$ & (9) & $(10)$ & (11) & $(12)$ \\
\hline (log-)Stock Price $t$ & $\begin{array}{l}0.63^{* *} \\
(0.27)\end{array}$ & $\begin{array}{l}0.70^{* *} \\
(0.33)\end{array}$ & $\begin{array}{l}0.68^{* *} \\
(0.27)\end{array}$ & $\begin{array}{l}0.35^{* *} \\
(0.16)\end{array}$ & $\begin{array}{c}0.21 \\
(0.29)\end{array}$ & $\begin{array}{l}0.49^{*} \\
(0.26)\end{array}$ & $\begin{array}{c}0.27 \\
(0.27)\end{array}$ & $\begin{array}{c}0.10 \\
(0.32)\end{array}$ & $\begin{array}{l}0.85^{*} \\
(0.45)\end{array}$ & $\begin{array}{l}0.45^{*} \\
(0.26)\end{array}$ & $\begin{array}{c}0.20 \\
(0.60)\end{array}$ & $\begin{array}{c}0.56 \\
(0.53)\end{array}$ \\
\hline Financial Market Controls & - & - & Yes & - & - & Yes & - & - & Yes & - & - & Yes \\
\hline Balance Sheet Controls & - & - & Yes & - & - & Yes & - & - & Yes & - & - & Yes \\
\hline Bank FE & Yes & Yes & Yes & Yes & Yes & Yes & Yes & Yes & Yes & Yes & Yes & Yes \\
\hline Country x Quarter FE & - & Yes & Yes & - & Yes & Yes & - & Yes & Yes & - & Yes & Yes \\
\hline $\mathrm{Nb}$ bank groups & 42 & 42 & 42 & 42 & 42 & 42 & 42 & 42 & 42 & 42 & 42 & 42 \\
\hline $\mathrm{Nb}$ countries & 12 & 12 & 12 & 12 & 12 & 12 & 12 & 12 & 12 & 12 & 12 & 12 \\
\hline $\mathrm{T}$ & 33 & 33 & 33 & 33 & 33 & 33 & 33 & 33 & 33 & 33 & 33 & 33 \\
\hline $\begin{array}{l}\text { S.E. } \\
\text { Obs. }\end{array}$ & $\begin{array}{c}\text { Clust. } \\
1367\end{array}$ & $\begin{array}{c}\text { Clust. } \\
1367\end{array}$ & $\begin{array}{c}\text { Clust. } \\
1367\end{array}$ & $\begin{array}{c}\text { Clust. } \\
1367\end{array}$ & $\begin{array}{c}\text { Clust. } \\
1367\end{array}$ & $\begin{array}{c}\text { Clust. } \\
1367\end{array}$ & $\begin{array}{c}\text { Clust. } \\
1367\end{array}$ & $\begin{array}{c}\text { Clust. } \\
1367\end{array}$ & $\begin{array}{c}\text { Clust. } \\
1367\end{array}$ & $\begin{array}{c}\text { Clust. } \\
1367\end{array}$ & $\begin{array}{c}\text { Clust. } \\
1367\end{array}$ & $\begin{array}{c}\text { Clust. } \\
1367\end{array}$ \\
\hline
\end{tabular}


Table III

First-stage regression

This table presents the first-stage regression: bank stock prices are regressed over predicted returns and other covariates. The panel runs from 2010Q2 to 2019Q2. The dependent variables is the log- stock price. The instrumental variable is the predicted return that a bank should experience provided the actual return of the Euro STOXX ex Financials Index and the historical association of the bank stock price with this index. Stock prices, earnings per share, dividends per share, and CDS prices are measured at the banking group level. Balance sheet controls are at the unconsolidated level. Standard errors are clustered at the banking group level, and t-statistics are in parenthesis. Statistical significance: ${ }^{*} p<0.10,{ }^{* *}$ $p<0.05,{ }^{* * *} p<0.01$.

\begin{tabular}{|c|c|c|c|c|}
\hline \multicolumn{5}{|l|}{ Dependent Variable: } \\
\hline & $\begin{array}{c}(1) \\
(\log -) \text { Stock }_{\text {Price }}\end{array}$ & $\begin{array}{c}(2) \\
(\log -) \text { Stock Price } \\
t\end{array}$ & $\begin{array}{c}(3) \\
(\log -) \text { Stock Price } t\end{array}$ & $\begin{array}{c}(4) \\
(\log -) \text { Stock } \text { Price }_{t}\end{array}$ \\
\hline Predicted Return $_{t}$ & $\begin{array}{c}0.95^{* * *} \\
(0.18)\end{array}$ & $\begin{array}{c}0.99^{* * *} \\
(0.28)\end{array}$ & & $\begin{array}{c}1.07^{* * *} \\
(0.19)\end{array}$ \\
\hline$(\log -)$ Earnings per Share $t$ & & & $\begin{array}{c}0.24^{* * *} \\
(0.07)\end{array}$ & $\begin{array}{c}0.23^{* * *} \\
(0.07)\end{array}$ \\
\hline$\left(\log\right.$-)Dividend per Share ${ }_{t}$ & & & $\begin{array}{c}0.22 \\
(0.27)\end{array}$ & $\begin{array}{c}0.31 \\
(0.25)\end{array}$ \\
\hline$(\log -) \mathrm{CDS}_{t}$ & & & $\begin{array}{l}-0.09 \\
(0.07)\end{array}$ & $\begin{array}{l}-0.07 \\
(0.08)\end{array}$ \\
\hline Expected (log-)Earnings per Share ${ }_{t}^{t+4}$ & & & $\begin{array}{l}0.23^{* *} \\
(0.09)\end{array}$ & $\begin{array}{l}0.22^{* *} \\
(0.10)\end{array}$ \\
\hline Expected (log-)Dividend per Share ${ }_{t}^{t+4}$ & & & $\begin{array}{l}0.41^{* *} \\
(0.20)\end{array}$ & $\begin{array}{l}0.40^{* *} \\
(0.18)\end{array}$ \\
\hline$(\log -)$ Total Assets $t(\mathrm{M})$ & & & $\begin{array}{c}1.08^{* * *} \\
(0.32)\end{array}$ & $\begin{array}{c}1.17^{* * *} \\
(0.33)\end{array}$ \\
\hline Loans $_{t}\left(/\right.$ Assets $\left._{t}\right)$ & & & $\begin{array}{c}0.01 \\
(0.01)\end{array}$ & $\begin{array}{c}0.01 \\
(0.01)\end{array}$ \\
\hline Non-Financial Assets $t$ (/Assets $t)$ & & & $\begin{array}{c}-0.38^{* *} \\
(0.14)\end{array}$ & $\begin{array}{c}-0.38^{* * *} \\
(0.13)\end{array}$ \\
\hline Capital and Reservest $\left(/\right.$ Assets $\left._{t}\right)$ & & & $\begin{array}{l}0.00 \\
(0.02)\end{array}$ & $\begin{array}{l}0.00 \\
(0.02)\end{array}$ \\
\hline $\operatorname{Deposits}_{t}\left(/\right.$ Assets $\left._{t}\right)$ & & & $\begin{array}{l}-0.01 \\
(0.01)\end{array}$ & $\begin{array}{l}-0.01 \\
(0.01)\end{array}$ \\
\hline Bank FE & Yes & Yes & Yes & Yes \\
\hline Country x Quarter FE & - & Yes & Yes & Yes \\
\hline Nb banks & 68 & 68 & 68 & 68 \\
\hline $\mathrm{Nb}$ countries & 12 & 12 & 12 & 12 \\
\hline $\mathrm{T}$ & 33 & 33 & 33 & 33 \\
\hline Nb bank groups & 42 & 42 & 42 & 42 \\
\hline S.E. & Clust. & Clust. & Clust. & Clust. \\
\hline $\mathrm{R}^{2}$ & 0.94 & 0.98 & 0.98 & 0.98 \\
\hline Obs. & 1367 & 1367 & 1367 & 1367 \\
\hline
\end{tabular}


Table IV

The effect of the bank stock price on bank loan supply: IV estimates

This table presents the IV estimates of the effect of banks' (log-) stock price on their loan supply and investment in securities. The panel runs from 2010Q2 to 2019Q2. The dependent variables are the difference, scaled by total assets, of, (3), loans to monetary and financial institutions in column (3), securities held in column (4). Column (5) reports the effect on total asset growth. The instrumental variable is the predicted return that a bank should experience provided the actual return of the Euro STOXX ex Financials Index and the historical association of the bank stock price with this index. 'Financial Market Controls' include the (log-) earnings-per-share, (log-) dividends-per-share, (log-) CDS price, (log-) earnings-per-share at $t+4$, and (log-) dividends-per-share at $t+4$. 'Balance Sheet Controls' comprise the (log-) total assets, loans-to-assets ratio, non-financial-assets ratio, capital-to-assets ratio, and deposits-to-assets ratio. Stock prices, earnings per share, dividends per share, and CDS prices are measured at the banking group level. Balance sheet controls are at the unconsolidated level. Standard errors are clustered at the banking group level, and t-statistics are in parenthesis. Statistical significance:

${ }^{*} p<0.10,{ }^{* *} p<0.05,{ }^{* * *} p<0.01$.

\begin{tabular}{|c|c|c|c|c|c|}
\hline \multicolumn{6}{|l|}{ Dependent Variable: } \\
\hline \multirow{5}{*}{ (log-)Stock Price $t$} & (1) & (2) & $(3)$ & (4) & (5) \\
\hline & $\Delta$ Corporate Loans $t, t+4$ & $\Delta$ Household Loans $t, t+4$ & $\Delta$ MFI Loans $t, t+4$ & $\Delta$ Securities $_{t, t+4}$ & $\Delta$ Total Assets $t, t+4$ \\
\hline & $\left(/\right.$ Assets $\left._{t}\right)$ & $\left(/\right.$ Assets $\left._{t}\right)$ & $\left(/\right.$ Assets $\left._{t}\right)$ & $\left(/\right.$ Assets $\left._{t}\right)$ & $\left(/\right.$ Assets $\left._{t}\right)$ \\
\hline & $1.61^{* *}$ & $1.60^{* *}$ & 0.47 & 1.66 & $6.54^{* *}$ \\
\hline & $(0.78)$ & $(0.64)$ & $(1.14)$ & $(1.47)$ & $(2.55)$ \\
\hline Financial Market Controls & Yes & Yes & Yes & Yes & Yes \\
\hline Balance Sheet Controls & Yes & Yes & Yes & Yes & Yes \\
\hline Bank FE & Yes & Yes & Yes & Yes & Yes \\
\hline Country x Quarter FE & Yes & Yes & Yes & Yes & Yes \\
\hline $\mathrm{Nb}$ bank groups & 42 & 42 & 42 & 42 & 42 \\
\hline Nb banks & 68 & 68 & 68 & 68 & 68 \\
\hline $\mathrm{Nb}$ countries & 12 & 12 & 12 & 12 & 12 \\
\hline $\mathrm{T}$ & 33 & 33 & 33 & 33 & 33 \\
\hline S.E. & Clust. & Clust. & Clust. & Clust. & Clust. \\
\hline IV & Yes & Yes & Yes & Yes & Yes \\
\hline First-stage Fisher & 31.6 & 31.6 & 31.6 & 31.6 & 31.6 \\
\hline Obs. & 1367 & 1367 & 1367 & 1367 & 1367 \\
\hline
\end{tabular}


Table V

The effect of the bank stock price on the bank funding

This table presents the IV estimates of the effect of banks' (log-) stock price on their funding. The panel runs from 2010Q2 to 2019Q2. The dependent variables are the difference, normalized by total assets, of, respectively, deposits in column (1), securities issued (other than shares) in column (2), capital and reserves in column (3). The instrumental variable is the predicted return that a bank should experience provided the actual return of the Euro STOXX ex Financials Index and the historical association of the bank stock price with this index. 'Financial Market Controls' include the (log-) earningsper-share, (log-) dividends-per-share, (log-) CDS price, (log-) earnings-per-share at $t+4$, and (log-) dividends-per-share at $t+4$. 'Balance Sheet Controls' comprise the (log-) total assets, loans-to-assets ratio, non-financial-assets ratio, capitalto-assets ratio, and deposits-to-assets ratio. Stock prices, earnings per share, dividends per share, and CDS prices are to-assets ratio, and deposits-to-assets ratio. Stock prices, earnings per share, dividends per share, and CDS prices are
measured at the banking group level. Balance sheet controls are at the unconsolidated level. Standard errors are clustered measured at the banking group level. Balance sheet controls are at the unconsolidated level. Standard errors are clustered
at the banking group level, and t-statistics are in parenthesis. Statistical significance: ${ }^{*} p<0.10,{ }^{* *} p<0.05,{ }^{* * *} p<0.01$.

Dependent Variable:

\begin{tabular}{lccc}
\hline & $(1)$ & $(2)$ & $(3)$ \\
& $\Delta$ Deposits $_{t, t+4}\left(/\right.$ Assets $\left._{t}\right)$ & $\Delta$ Securities issued $_{t, t+4}\left(/\right.$ Assets $\left._{t}\right)$ & $\Delta$ Capital and Reserves $_{t, t+4}\left(/\right.$ Assets $\left._{t}\right)$ \\
\hline (log-)Stock Price $t$ & 3.49 & $1.72^{*}$ & $1.10^{* *}$ \\
& $(2.15)$ & $(1.02)$ & $(0.53)$ \\
\hline Financial Market Controls & Yes & Yes & Yes \\
Balance Sheet Controls & Yes & Yes & Yes \\
Bank FE & Yes & Yes & Yes \\
Country x Quarter FE & Yes & Yes & 42 \\
Nb bank groups & 42 & 42 & 68 \\
Nb banks & 68 & 68 & 12 \\
Nb countries & 12 & 12 & 33 \\
T & 33 & 33 & Clust. \\
S.E. & Clust. & Clust. & Yes \\
IV & Yes & 31.6 & 31.6 \\
First-stage Fisher & 31.6 & 1367 & 1367 \\
Obs. & 1367 & &
\end{tabular}


Table VI

The effect of the bank stock price on the bank bond yields

This table presents the estimates of the effect of banks' (log-) stock price on their bond yields. The sample is composed of bonds issued by banking groups headquartered in France, Germany, Italy, or Spain, and each observation refers to a bond in a quarter. The panel runs from 2010Q2 to 2019Q2. The dependent variable is a bond yield in percentage points. The instrumental variable is the predicted return that a bank should experience provided the actual return of the Euro STOXX ex Financials Index and the historical association of the bank stock price with this index. 'Financial Market Controls' include the (log-) earnings-per-share, (log-) dividends-per-share, (log-) earnings-per-share at $t+4$, and (log-) dividends-per-share at $t+4$. 'Balance Sheet Controls' comprise the (log-) total assets, loans-to-assets ratio, non-financial-assets ratio, capital-to-assets ratio, and deposits-to-assets ratio. All such control variables are measured at the banking group level. Standard errors are clustered at the bond level, and t-statistics are in parenthesis. Statistical significance: ${ }^{*} p<0.10,{ }^{* *} p<0.05,{ }^{* * *} p<0.01$.

\begin{tabular}{lccc}
\hline Dependent Variable: & & & \\
& $(1)$ & $(2)$ & $(3)$ \\
& Bond Yield $t$ & Bond Yield $_{t}$ & Bond Yield $_{t}$ \\
\hline (log-)Stock Price $t$ & $-1.22^{* * *}$ & $-0.61^{*}$ & $-0.53^{* *}$ \\
& $(0.19)$ & $(0.36)$ & $(0.27)$ \\
Bond Duration $t$ & & & -0.09 \\
& & & $(0.19)$ \\
\hline Financial Market Controls & - & - & Yes \\
Balance Sheet Controls & - & - & Yes \\
Bond FE & Yes & Yes & Yes \\
Country x Quarter FE & - & Yes & Yes \\
Nb bank groups & 18 & 18 & 18 \\
Nb countries & 4 & 4 & 4 \\
T & 33 & 33 & 33 \\
S.E. & Clust. & Clust. & Clust. \\
IV & - & - & Yes \\
First-stage Fisher & - & - & 298.9 \\
Obs. & 6293 & 6293 & 6293 \\
\hline
\end{tabular}

